\title{
MENULIS TERSTRUKTUR SEBAGAI URGENSI PEMBELAJARAN MAHARAH AL-KITABAH
}

\author{
Juhaeti Yusuf, Ahmad Zaki Alhafidz, Muhammad Fahmi Luthfi \\ Universitas Islam Negeri Raden Intan Lampung
}

Jl. Let. Kol. Endro Suratmin, Sukarame, Bandar Lampung, Lampung 35131

e-mail: juhaeti.yusuf@gmail.com

\begin{abstract}
Abstrak
Kitabah atau menulis adalah aktivitas yang berupa suatu kegiatan yang dilakukan hanya dengan menggerakkan tangan dan alat tulis sebagai ekspresi yang sangat berbeda dengan keadaan komunikasi lisan tanpa adanya suara, nada, dan mimik. Menulis adalah suatu kegiatan yang tercipta dari kebiasaan yang menjadikan suatu keterampilan berbahasa yang tidak mudah, karena seorang penulis harus mempunyai skill dan pengetahuan tentang kaidah-kaidah penulisan sesuai dengan kaidah yang ada dalam ilmu bahasa Arab, cara berkomunikasi melalui tulisan tulisan yang mudah dipahami oleh pembaca serta kaidah-kaidah seni tata bahasa untuk menambah nilai estetika di dalam karya tulis dan menambah ketertarikan pembaca. Menulis terstruktur (Al Insya' Al-Muwajjah) merupakan metode pengajaran dengan cara memerintahkan anak didik untuk membuat suatu kalimat sempurna ataupun karangan dengan beberapa arahan dan ketentuan dari pengajar.
\end{abstract}

Kata Kunci: Maharah Al-Kitabah; Metode Pengajaran; Menulis

Terstruktur.

\section{A. Pendahuluan}

Pembelajaran bahasa Arab, para ahli Bahasa membagi keterampilan berbahasa Arab yang disebut dengan Maharah menjadi 4 keterampilan utama, yaitu: Maharah Al-kalam (Keterampilan Berbicara), Maharah Al Istima' (Keterampilan mendengar), Maharah Al-Qira'ah (keterampilan membaca), dan Maharah Al Kitabah (keterampilan menulis). Keempat keterampilan 
tersebut merupakan rangkaian keterampilan yang harus dipelajari dan saling melengkapi saat proses belajar mengajar bahasa Arab itu sendiri dengan kadar isi kandungan yang tersusun pada setiap level pembelajaran. Untuk langkah terakhir yang dilakukan setelah adanya kegiatan menyimak, berbicara dan membaca sangat membantu dalam menciptakan ide pikiran mengenai apa yang akan dituangkan dalam suatu tulisan, inilah karakteristik yang membedakan dengan kemahiran lainnya, meski ada pula tingkat persamaannya. Namun demikian maharah al-kitabah (keterampilan menulis) merupakan hal yang penting dalam proses kegiatan belajar mengajar suatu bahasa.

Menulis adalah suatu kegiatan menuangkan ide pikiran yang penulis miliki untuk menghasilkan suatu tulisan kepada pembaca, yang tentunya berbeda dengan kemampuan berbicara yang terdiri dari sarana berkomunikasi aktif dengan orang lain sehingga pendengar akan mengerti dan memahami apa yang diungkapkan oleh seseorang. Sedangkan kelebihan khusus dari menulis adalah sarana komunikasi yang tidak terikat dalam waktu dan wadah tertentu bahkan dapat menghasilkan sebuah tulisan sesuai keilmuan tertentu yang berupa naskah, artikel dan buku yang dapat dibaca lalu di pahami kapan pun dan oleh siapa pun.

Keterampilan menulis dalam pembelajaran bahasa Arab merupakan keterampilan pada tingkat tertinggi dalam kemahiran bahasa. Bahkan keterampilan menulis dalam bahasa Arab harus mulai mengenal konvensi penulisan yang benar terutama dalam penulisan bahasa Arab. Karena hal tersebut akan mempengaruhi urutan penulisan yang tidak sesuai dengan ketepatan aturan bahasa Arab. Sedangkan aturan bahasa Arab dikenal sebagai materi pembelajaran imla'. ${ }^{1}$

Menurut Aziz Fakhrurozi menulis merupakan suatu aktivitas kegiatan berinteraksi yang dilakukan tanpa adanya memerlukan suara, intonasi, raut muka, gerakan seperti halnya kegiatan komunikasi lisan. ${ }^{2}$ Meski diakui keterampilan berbahasa yang cukup sulit karena seorang penulis harus memiliki skill dan pengetahuan tentang kaidah-kaidah penulisan dengan

\footnotetext{
${ }^{1}$ Ida Suryani Wijaya dan Luluk Humairo Pimada, "Ta'lim al-Imla” bi Al-Wasit alMuta'addidah li Tarqiyyah Maharah al-Kitabah fi al-Lughah al-'Arabiyyah," Jurnal Al-Bayan: Jurnal Jurusan Pendidikan Bahasa Arab 11, no. 2 (2019): 320-39, https://doi.org/10.24042/albayan.v11i2.5266.

${ }^{2}$ Aziz Fakhrurrozi dan Erta Mahyudin, Pembelajaran Bahasa Arab (Jakarta: Direktorat Jenderal Pendidikan Islam Kementerian Agama, 2012), h. 347.
} 
menggunakan kaidah nahwu dan shorof serta ilmu lain yang berkaitan dengan bahasa Arab dalam penulisan yang baik dan benar, cara berkomunikasi melalui tulisan tulisan yang mudah dipahami oleh pembaca serta kaidahkaidah seni tata bahasa untuk menambah nilai estetika di dalam karya tulis dan menambah ketertarikan pembaca.

Dalam pembelajaran Maharah al kitabah memiliki tahap-tahap yang harus dipelajari secara konsisten, seperti tahapan dasar yang membahas tentang kaidah penulisan huruf hijaiyah secara baik dan benar, menyambung huruf hijaiyah sehingga menjadi suatu kata, kalimat, paragraf dan seterusnya sampai kepada mengarang secara terstruktur dan mengarang bebas yang itu semua harus didasari dengan ilmu yang berhubungan pedoman penulis yang sesuai dengan teori, maka Maharah al kitabah merupakan keterampilan yang kompleks dan memiliki proses serta tahapan yang saling melengkapi. Konsep pembelajaran secara bertahap itu sering disebut dengan konsep Gradasi, yaitu proses pembelajaran yang dibangun atas dasar perencanaan yang matang yang dimulai tentang hal-hal yang ringan lalu berlanjut ke yang agak berat dan kemudian dari yang berat ke yang lebih berat lagi bahkan ke yang lebih kompleks lagi. ${ }^{3}$

Prosedur dan teknik pengajaran Maharah al Kitabah adalah sebagai berikut:

1. Keterampilan sebelum menulis

2. Pengajaran menulis huruf

3. Pengajaran menyalin

4. Pengajaran dikte

5. Pengajaran menulis terstruktur

6. Pengajaran menulis bebas. ${ }^{4}$

Dalam artikel kali ini akan dibahas tentang pengajaran menulis terstruktur sebagai urgensi pembelajaran Maharah al Kitabah (keterampilan menulis), dengan rumusan masalah: Apa pengertian Maharah al Kitabah (keterampilan menulis) dan apa yang dimaksud dengan menulis terstruktur serta apa urgensi menulis terstruktur dalam pembelajaran Maharah al Kitabah (keterampilan menulis).

\footnotetext{
${ }^{3}$ Muhammad Ali Al-Khuli, Strategi Pembelajaran Bahasa Arab (Yogyakarta: Bagan Publishing, 2010), h. 131.

${ }^{4}$ Aziz Fachrurrozi dan Erta Mahyuddin, Teknik Pembelajaran Bahasa Arab (Bandung: Pustaka Cendekia Utama, 2011), h. 150-153.
} 


\section{B. Pembahasan}

Menulis atau maharah kata dasarnya هر yang merupakan kata kerja yang telah lampau lalu mengalami perubahan menjadi kata jadian yaitu مهارة yang merupakan bentuk mashdar yang mempunyai arti keterampilan atau kemahiran. Untuk kata كتابة yang merupakan bentuk masdar dari kata yang berasal dari kata كتب yang merupakan kata dasar yang merupakan kata kerja yang telah lampau yang mempunyai arti menulis. Makna kitabah itu sendiri adalah serangkaian kata yang terstruktur dari kumpulan kata yang mempunyai arti yang dapat dipahami oleh pembaca. Menurut ilmu bahasa kitabah adalah rangkaian dari kata yang membentuk suatu kalimat yang tersusun sesuai dengan fungsinya sehingga dapat dipahami pengertiannya, dengan kata lain bahwa, kitabah akan akan mempunyai arti dan makna yang dapat dipahami oleh pembaca apabila kitabah terbentuk dan tersusun dengan baik menurut tatanannya sehingga dengan tulisan yang baik para penulis dapat mengekspresikan apa yang tersirat di hatinya sesuai dengan apa yang akan disampaikan oleh akal pikirannya, dengan kata yang tersusun rapi dengan kaidah-kaidah ilmu bahasa Arab maka suatu tulisan yang baik akan komunikatif seolah-olah pembaca sedang berbicara langsung dengan si penulis. $^{5}$

Menulis adalah komunikasi yang menggunakan bahasa verbal dengan simbol-simbol tulis sebagai mediumnya. Kitabah merupakan bentuk komunikasi yang terdiri dari 4 unsur yang ada dalam komponen menulis, yaitu (1) penulis adalah si penyampai pesan, (2) pesan adalah sesuatu yang akan disampaikan oleh penulis, (3) tulisan adalah berupa lambang-lambang bunyi bahasa tulis yang terdiri dari rangkaian huruf yang membentuk kalimat dilengkapi dengan tanda bacanya, serta (4) sedangkan pembaca adalah orang yang menerima pesan melalui tulisan yang dibacanya mengenai apa yang ditulis oleh penulis. Menulis merupakan aktivitas berbahasa yang mempunyai tujuan dan berfungsi sebagai berikut:

1. Fungsi personality, yaitu bertujuan untuk menuangkan ide pikiran, sikap atau perasaan penulis yang dituangkan dalam tulisan baik berupa artikel, surat ataupun catatan harian.

2. Fungsi direktif berupa instrumen yang diciptakan untuk memancing pembaca untuk mengambil sikap serta secara spontan memberikan saran dan pendapatnya.

${ }^{5}$ Sitti Kuraedah, "Aplikasi Maharah Kitabah Dalam Pembelajaran Bahasa Arab," AlTa'dib 8, no. 2 (2015): 82-98, https://doi.org/10.31332/atdb.v8i2.412. 
3. Fungsi interaksional, dalam hal ini dapat berfungsi sebagai jalinan hubungan sosial.

4. Fungsi informatif, yang bisa berfungsi untuk sarana mediasi dalam penyaluran informasi baik info yang hanya sekedar berita bahkan termasuk ilmu pengetahuan yang sedang trend di masa itu.

5. Fungsi heuristik, suatu tulisan yang mempunyai makna untuk belajar untuk mendapatkan informasi yang diperlukan.

6. Fungsi estetis, sebuah informasi yang bertujuan untuk mengungkapkan suatu keindahan. ${ }^{6}$

Adapun yang dimaksud dengan Maharah al-kitabah (kemahiran atau keterampilan menulis), adalah: kemampuan untuk mengaktualisasikan perihal yang dibaca serta yang didengar lalu mampu menuangkan ke dalam rangkaian kata-kata yang membentuk tulisan yang tersusun sesuai kaidah ilmu bahasa Arab dengan tujuan dapat dipahami oleh si pembaca. Dari keempat kemahiran yang ada dalam kemahiran berbahasa, kemahiran menulis adalah kemahiran yang ada setelah kemahiran mendengar, berbicara serta membaca. Helmi Kamal berpendapat bahwa keterampilan yang paling tinggi adalah kemahiran berbahasa adalah menulis. ${ }^{7}$

Menulis terstruktur (Al Insya' Al Muwajjah) merupakan metode pengajaran dengan cara memerintahkan anggota didik untuk membuat suatu kalimat sempurna ataupun karangan dengan beberapa arahan dan ketentuan dari pengajar. Seperti contoh : seorang anggota didik memulai belajar dengan menuliskan satu kata, kemudian dapat diarahkan oleh pengajar menjadi beberapa susunan instruksi sebagai berikut :

1. Membuat satu kalimat sempurna dari satu kata tersebut

2. Membuat dua kalimat dari satu kata tersebut

3. Menyatukan dua kalimat yang telah dibuat

4. Membuat beberapa kalimat tambahan yang sesuai dengan kalimat sebelumnya sehingga menjadi suatu paragraf. ${ }^{8}$

Menulis terstruktur ini merupakan tahapan pembelajaran bagi anggota didik yang sudah memahami tahapan-tahapan sebelumnya, seperti penulisan

${ }^{6}$ Mohamad Yunus, Keterampilan Menulis (Jakarta: Universitas Terbuka, 2014), h.

1.4 .

${ }^{7}$ Helmi Kamal, "Maharah Al-Kitabah Wa Thariqah Ta'limiha," Ulul Albab 12, no. 2 (2010): 60.

${ }^{8}$ Anisa Novi, “Efektivitas Metode Insya' Muwajjah dalam Meningkatkan Maharah Kitabah" (Skripsi, Kudus, STAIN Kudus, 2017), h. 15. 
huruf hijaiyah, keterampilan menyalin dan ketangkasan akan imla' ataupun dikte bahasa arab begitu pula dengan kaidah nahwu dan shorof serta perbendaharaan mufrodat yang banyak untuk membantu para anggota didik di dalam membuat karangan tersebut walaupun masih dalam arahan pengajar.

Bentuk-bentuk serta tahapan yang ada dalam menulis terstruktur adalah sebagai berikut:

1. Bentuk kalimat yang sepadan

Dalam tahap ini siswa diperintahkan untuk membuat kalimat yang sepadan dengan kalimat contoh yang telah diberikan. Dimana terlebih dahulu disiapkan beberapa contoh kalimat dengan pola kalimat tertentu, sepadan di sini baik sepadan kata kerjanya, subjeknya ataupun yang lainnya, seperti, درسه كتب الولد kata yang dapat dipadankan dengan kata yang digarisbawahi, adalah البنت maka siswa diminta untuk mencari kata yang sepadan dengan البنت adalah الولد jadiswa akan mengganti kalimat tersebut sebagai berikut: درسها كتبت البنت.

2. Alinea yang sepadan

Guru menyiapkan sebuah alinea dalam bahasa Arab, kemudian siswa diperintahkan untuk menuliskan kembali alinea tersebut dengan arahan yang dituntun oleh guru, misalnya mengubah salah satu kata sebagai panduannya. Contoh ada nama seorang pemuda dengan nama Ahmad yang menjadi subjek atau pelaku yang terdapat dalam alinea tersebut, maka siswa diminta untuk menulis kembali alinea tersebut dengan mengubah nama pemuda tersebut menjadi nama seorang pemudi dengan nama Fatimah misalnya, dengan mengubah subjeknya secara otomatis semua akan berubah sesuai dengan kaidah nahwu dan sharaf, baik berkaitan dengan fi'il, dhamir, dan lain-lainnya yang berkaitan dengan alinea di atas.

3. Melengkapi kalimat yang kosong

Tahapan ini adalah siswa diperintahkan untuk melengkapi kalimat yang salah satu katanya masih kosong. Karena kalimat merupakan susunan kata yang terdiri dari berbagai jenis baik itu kata kerja, subjek, objek dan berupa keterangan yang lain. Kata merupakan susunan dari beberapa huruf yang mempunyai makna dan bersifat bebas. Dalam bentuk ini siswa diperintahkan untuk mengisi kata yang kosong sesuai dengan ketentuan yang sesuai dengan kata yang tersedia. Kata yang 
kosong bisa jadi merupakan kata kerja, huruf jar, athaf, dan bentuk lainnya, seperti:

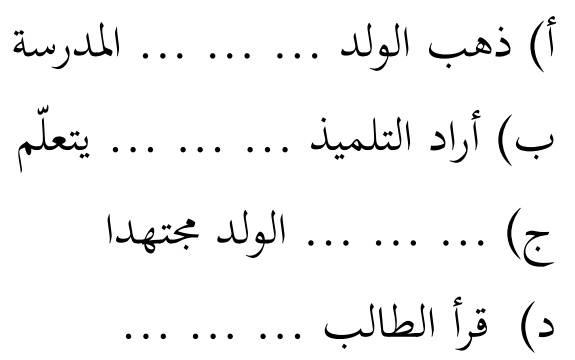

4. Menyusun kata-kata

Guru menyajikan beberapa kata yang tak beraturan kemudian siswa diperintahkan untuk menyusun sehingga bisa membentuk kalimat yang sempurna dan benar sesuai dengan kaidah bahasa Arab sesuai dengan tingkat pendidikan siswa, contoh:

$$
\text { حلوة - أكل - تفاحة - عاصم }
$$

Maka kalimat yang benar setelah menyusun kata yang ada dalam soal di atas, adalah:

$$
\text { أكل عاصم تفاحة حلوة }
$$

5. Menyusun kalimat

Guru memberikan beberapa kalimat selanjutnya diberikan tugas kepada siswanya untuk menyusun kembali kalimat tersebut agar membentuk sebuah cerita dalam rangkaian satu alinea. Siswa tidak diperintahkan membuat kalimat namun hanya menyusun kalimat yang sudah disediakan oleh guru. Diharapkan setelah kalimat tersusun rapi membentuk sebuah cerita tentunya harus tetap memperhatikan susunan, arti, waktu dan tempatnya.

6. Mengubah kalimat

Si pelajar dihadapkan beberapa macam kalimat diberikan kalimat kemudian pelajar wajib mengganti pola kalimat yang ada menjadi kalimat yang sesuai dengan apa yang diperintahkan guru, misalnya diubah menjadi kalimat manfi', mushbat, istifham, khabariyah, ta'ajjubiyah, madhi, mudhari', amar ataupun majhul.

7. Mengabungkan beberapa kalimat

Pelajar diberi tugas untuk menggabungkan dua kalimat dengan menambahkan kata penghubung di tengahnya sehingga membentuk 
kalimat yang sempurna dengan adanya beberapa unsur seperti kata kerja, subjek, objek dan lainnya. Agar siswa dapat menggabungkannya tentu dituntut untuk memahami arti dan maksud dari kalimat tersebut, siswa bebas meletakkan kata penghubungnya dengan melihat arti dan maknanya. Seperti contoh:

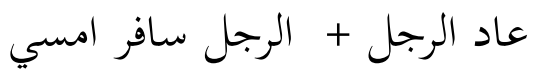

digabungkan menjadi :

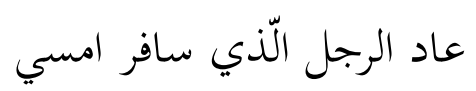

8. Melengkapi kalimat

Pelajar dihadapkan dengan potongan kalimat kemudian pelajar diberi tugas untuk mengisi kata yang kosong sehingga akan membentuk kalimat yang sempurna dan dapat dimengerti. Kata yang kosong bisa dari pokok kalimat atau anak kalimat, bisa subjeknya atau objeknya. Ini diharapkan pelajar mampu menganalisis terlebih dahulu arti setiap kata sehingga mampu mengisi kata yang kosong. Sebagaimana contoh berikut:

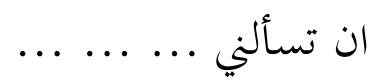

Beberapa poin di atas merupakan contoh bentuk pengajaran Maharah Al Kitabah dalam tahapan menulis terstruktur, tidak hanya terbatas dengan 8 bentuk instruksi di atas, namun kembali lagi ke kreativitas pengajar dalam memberi bentuk-bentuk instruksi yang lebih bervariasi lagi agar para anggota didik lebih tertarik di dalam mempelajari Maharah Al Kitabah

Menulis terstruktur ( Al Insya' Al-Muwajjah ) merupakan tahapan yang memiliki peranan penting dalam pembelajaran Maharah Al-Kitabah karena tahapan ini merupakan tahapan transisi dari pemahaman dasar anggota didik tentang keterampilan menulis bahasa Arab menuju tahapan lanjutan yang lebih membebankan anggota didik untuk mengembangkan keterampilan menulisnya secara individu tanpa arahan dari pengajar lagi.

Berikut beberapa hal yang menjelaskan urgensi tahapan menulis terstruktur di dalam pembelajaran Maharah Al-Kitabah:

1. Sebagai sarana pendekatan seorang pengajar terhadap anggota didik sehingga dapat lebih memahami kualitas pemahaman anggota tentang materi yang disampaikan

2. Tahapan ini memiliki bentuk-bentuk instruksi yang beragam agar siswa tidak bosan dengan gaya penyampaian materi oleh pengajar 
3. Apabila terdapat kesalahan anggota didik dalam menjawab, perbaikan yang dilakukan oleh pengajar bisa lebih objektif

4. Tidak menghabiskan durasi waktu yang lama di dalam penyelesaian tugas

5. Sebagai sarana untuk memperluas pemikiran anggota didik

6. Sebagai sarana pengembangan keterampilan berbahasa secara intensif.

Adapun tujuan pengajaran menulis terstruktur adalah sebagai berikut :

1. Memperluas wawasan pelajar

2. Memperbanyak perbendaharaan mufrodat dan uslub bagi para pelajar

3. Pelajar dapat menuliskan sesuai dengan ide dan kemampuan yang dimilikinya, ditulis dengan tuntunan kaidah penulisan yang baik sehingga mendapat arti yang sempurna

4. Mengarahkan pelajar agar terus belajar untuk memantapkan pemahaman mereka

5. Para pelajar diharapkan untuk mendalami ilmu yang berkaitan dengan AlQur'an serta Hadits yang di dalamnya mengkaji tentang kaidah ilmu nahwu dan sharf dengan tingkat uslub yang baik dan indah

6. Peserta didik mengetahui bentuk-bentuk kalimat yang dibaca ataupun ditulis di dalam buku-buku bahasa Arab

7. Mengenalkan kepada anggota didik bentuk-bentuk uslub yang sering digunakan sehari hari

8. Memperbaiki bahasa Arab anggota didik dan dapat menggunakannya dalam kegiatan sehari hari. ${ }^{9}$

Menulis terstruktur mempunyai keunikan tersendiri serta sangat kompleks sekali untuk ada beberapa langkah yang mesti diperhatikan oleh guru, sebagaimana yang dikatakan Munir, di antaranya:

1. Oleh karena tingkat pengetahuan pelajar sangat bervariasi maka guru harus pandai mencari materi yang akan diajarkan disesuaikan dengan latar belakang pendidikannya. Namun guru harus tetap mengoptimalkan mutu dari kemahiran menulis. Apalagi mengingat jenis latihan menulis tingkat kesulitannya tidak sama.

2. Setiap kali guru memberikan latihan menulis terstruktur guru harus menyampaikan koreksian perbaikan yang dilakukan pelajar pada latihan sebelumnya. Kemudian bersama pelajar guru menjelaskan kembali susunan kalimat yang seharusnya, diharapkan latihan selanjutnya tulisan pelajar dapat lebih baik.

\footnotetext{
${ }^{9}$ Novi, h. 15.
} 
3. Hendaknya guru memberikan tugas sesuai dengan kemampuan dan menggunakan kata-kata yang telah dimiliki pelajar.

4. Tugas yang sudah selesai hendaknya dikoreksi. Koreksi dapat dilakukan oleh guru, atau silang di mana pelajar saling mengoreksi tugas kawannya, bahkan bisa dilakukan oleh pelajar itu sendiri dengan terlebih dahulu dijelaskan secara singkat tentang tugas tadi.

5. Langkah selanjutnya guru mengajak pelajar untuk mendiskusikan tingkat kesulitan dan letak kesalahan pada latihan masing-masing pelajar. Serta guru dapat langsung memberikan tugas tambahan untuk membiasakan pelajar latihan menulis.

6. Terakhir pelajar diperintahkan untuk menulis kembali mengenai tugas latihan tadi, baik beberapa kalimat yang dianggap perlu atau bahkan seluruhnya. ${ }^{10}$

\section{Simpulan}

Maharah Al-Kitabah (kemahiran atau keterampilan menulis) adalah: tingkat pengaplikasian dari apa yang dibaca dan didengar kemudian dituangkan dan disusun menjadi kalimat yang dapat memiliki makna sehingga para pembaca dapat memahaminya sesuai dengan alur pikir penulis. Keterampilan menulis ini adalah langkah akhir yang jatuh setelah keterampilan yang lainnya yaitu mendengar, membaca dan berbicara. Ada yang berpendapat bahwa keterampilan menulis adalah kemampuan tertinggi dari keempat kemahiran yang ada dalam kemahiran berbahasa. Menulis terstruktur (Al Insya' Al Muwajjah) merupakan metode pengajaran dengan cara memerintahkan anggota didik untuk membuat suatu kalimat sempurna ataupun karangan dengan beberapa arahan dan ketentuan dari pengajar. Menulis terstruktur ( $\mathrm{Al}$ Insya' Al Muwajjah) merupakan tahapan yang memiliki peranan penting dalam pembelajaran Maharah Al-Kitabah karena tahapan ini merupakan tahapan transisi dari pemahaman dasar anggota didik tentang keterampilan menulis bahasa Arab menuju tahapan lanjutan yang lebih membebankan anggota didik untuk mengembangkan keterampilan menulisnya secara individu tanpa arahan dari pengajar lagi.

${ }^{10}$ Munir, Perencanaan Sistem Pengajaran Bahasa Arab (Jakarta: Kencana, 2017). 


\section{Daftar Pustaka}

Al-Khuli, Muhammad Ali. Strategi Pembelajaran Bahasa Arab. Yogyakarta: Bagan Publishing, 2010.

Fachrurrozi, Aziz, dan Erta Mahyuddin. Teknik Pembelajaran Bahasa Arab. Bandung: Pustaka Cendekia Utama, 2011.

Fakhrurrozi, Aziz, dan Erta Mahyudin. Pembelajaran Bahasa Arab. Jakarta:

Direktorat Jenderal Pendidikan Islam Kementerian Agama, 2012.

Kamal, Helmi. "Maharah Al-Kitabah Wa Thariqah Ta'limiha." Ulul Albab 12, no. 2 (2010): 60.

Kuraedah, Sitti. "Aplikasi Maharah Kitabah Dalam Pembelajaran Bahasa Arab." Al-Ta'dib 8, no. 2 (2015): 82-98. https://doi.org/10.31332/atdb.v8i2.412.

Munir. Perencanaan Sistem Pengajaran Bahasa Arab. Jakarta: Kencana, 2017.

Novi, Anisa. "Efektivitas Metode Insya' Muwajjah dalam Meningkatkan Maharah Kitabah." Skripsi, STAIN Kudus, 2017.

Wijaya, Ida Suryani, dan Luluk Humairo Pimada. “Ta'lim al-Imla' bi AlWasit al-Muta'addidah li Tarqiyyah Maharah al-Kitabah fi al-Lughah al-'Arabiyyah." Jurnal Al-Bayan: Jurnal Jurusan Pendidikan Bahasa Arab 11, no. 2 (2019): 320-39. https://doi.org/10.24042/albayan.v11i2.5266.

Yunus, Mohamad. Keterampilan Menulis. Jakarta: Universitas Terbuka, 2014. 
214 | Juhaeti Yusuf, Ahmad Zaki Alhafidz, Muhammad Fahmi Luthfi 